\author{
Душан М. ИВАНИЋ* \\ Универзитет у Београду \\ Филолошки факултет \\ Катедра за српску књижевност са \\ јужнословенским књижевностима
}

\title{
ФУНКЦИЈА КЊИЖЕВНОГ ДЈЕЛА У ПРЕПОРОДНОМ ДОБУ СРПСКЕ КУЛТУРЕ
}

\author{
„Сад се људи почињу као иза сна будити” (Обрадовић 1961: 503) \\ „Крик сербског рода звезде домаша већ” (Мушицки 1938: 98) \\ „Сербљин међ первима бити може” (Мушицки 1938: 95 )
}

\begin{abstract}
Препородно доба српске културе (и културе државно несамосталних словенских народа) обухвата период од 60-их година 18. вијека (дјеловање Захарија Орфелина, а нарочито Доситеја Обрадовића од 1783) до 40-их година 19. вијека. Стилски, поетички хетерогено (барок, класицизам, сентиментализам / предромантизам, романтизам), ово доба прожимају идеје просвјећивања, корисности, националног ослобођења, родољубља и слободе личности, те расправе о књижевном језику; обиљежава га и утемељење основних књижевних жанрова (лирика, религиозни еп, роман, усмена књижевност), са наглашеном свијешћу о њиховим функцијама у процесу препорода националне културе.

Кључне речи: препород, функција, просвијећеност, ослобођење, родољубље, језик, корисност, нација, жанр.
\end{abstract}

Препородно доба српске културе је двокрако. ${ }^{1}$ Оно обухвата и „Доситејево” и „Вуково” доба, тј. последње деценије 18. и прву половину 19. вијека. У првом

*dusan.div@gmail.com

${ }^{1}$ Појам препород је одавно уведен у научну литературу, али је под утицајима оријентисања проучавања на стил и на књижевне покрете, потиснут, између осталог и у настојању да се периодизација српске књижевности европеизира, да се појмовник историјске поетике (односно историје српске књижевности) усагласи с појмовницима водећих европских књижевности, француске, њемачке, енглеске (Скерлић и сви новији историчари српске књижевности. Не оспоравајући научну оправданост таквог приступа, прије свега што се уз помоћ истих појмова лакше претпостави сродност и упоредивост појава у књижевности различитих народа, у појму препород се налази шири културноисторијски став о процесу или стању новог рођења и преображаја онога што је некад постојало (као цјелина, држава, народна самосталност итд., без обзира колико је то и стварно тако било). Аналогно идеји о васкрсу државе (С. Новаковић, Васкрс државе српске) појављује се и идеја препорода националне културе, њеног преображаја, поновног рађања нечега што је пропало, потиснуто или ослабило. Вук Караџић је тај јаз између савременог стања српског народа и његове некадашње снаге и славе исказао у похвали Видаковићевим романима, тј. да је ьихов аутор заслужан што је читаоце сјетио („опоменуо”) „да смо и ми некад нешто били” (Караџић 1814: 18). Гледано културноисторијски, препород је доба обликовања националне кул- 
периоду Доситеј Обрадовић објављује програмске идеје о модернизацији/европеизацији српске културе (1783), у другом Вук поставља основе њене национализације и афирмише је у Европи. Препород се може разумјети као оживљавање, буђење уснулог (националног, државног, исконског, културног) бића малих или мањих словенских, балканских, средњоевропских народа, који нису имали ни државну самосталност, ни националну хомогеност, ни уређен књижевни језик, нити су били потпуније укључени у културне процесе у развијенијим земљама Европе, какви су се одвијали у Енглеској, Француској, Њемачкој, Италији и Русији. Милан Прелог је тај период, од 1780. до 1848, назвао словенском ренесансом, другим називом за препород међу словенским народима (Prelog 1924).

Извори и аргументи за ову тему су изричити у дјелима Доситеја Обрадовића, али се разумију и из алегоричних и параболичних порука његових претходника, савременика и млађих генерација. Орфелинов Плач Сербији (тј. Плач Србије) (1762/63) у основном смислу је порука о мучном положају српског народа у аустријској царевини. Пјесник пројектује колективно стање, критикује народне прваке и однос околних народа према Србима. И кад објављује историју Петра Великог (1774), Орфелин напомиње да су га на то „нагнале [...] жеља једноплемених и једнородних српских Народа и моја усрдност" (Орфелин 1970: 11). Лична и колективна (национална) жеља ће се повезивати у врло различитим функцијама књижевних дјела ове епохе. Доситеј у свом првом објављеном тексту, послије свих порука и поука, закључује да ће му и послије смрти највећа награда бити да људи кажу: „Он је љубио свој род" (Писмо Харалампију). Одређујући значај српске књиге/књиге за Србе (поука, полза, васпитање, забава/увеселеније), непрестано истиче љубав према свом роду (и сваком народу, колико је просвјећенији), те се цјелокупно Доситејево књижевно дјело може узети као непрестана, отворена посланица Србима и Српкињама (Иванић 2012), саопштена кроз мозаик облика и тема, са основним циљем да утврди право сваког човјека на слободно мишљење, на васпитање и учвршћивање основних етичких начела, те да подстакне одбацивање неразумних обичаја, сујевјерја и штетних установа (манастири).

Широк, разностран просвјетитетљски програм се у књижевним дјелима подређивао ауторским циљевима и жанровским конвенцијама (лирика, роман, приповијетка, комедија, трагедија, епиграм, сатира...), опште идеје су се преносиле као тенденција, преко дијелова радње или цијеле фабуле и преко концепције јунака (у драмским и приповједачким дјелима). Тај би се програм могао свести на заједнички циљ, на општу ползу (корист) као једну од најупадљивијих метонимија за просвјећивање и за јединство народа. Идеја ће се уобличавати према природи дјела (жанра), непосредно у прозним и пјесничким текстовима, у паратекстуалним сегментима или у засебним чланцима.

Иако је Доситеј огласио народни (говорни) језик као језик свјетовне књиге, питање природе тога језика, његове граматичке и графијске норме, остало је отворено до средине 19. вијека. Занимљиво је да се дилеме око језика брзо преносе међу ау-

туре и њених институција, с народним језиком и књижевношћу као темељима. Да додамо, ни овај појам није уско националан: не само што је преузет/преведен из западноевропске (италијанске) традиције већ се раширио у књижевностима тзв. малих народа европског југоистока и Средње Европе, обухвативши у исто вријеме руско-украјинску њижевност. 
торе лирике. Они су почели, у збиркама и у појединачним пјесмама, да расправљају о томе којим језиком, писмом, стилом, стихом и о каквој садржини српски пјесник треба да пише. Врло рано се испољава полемички и аутополемички однос према функцији појединих чинилаца дјела: језик (народни, славјански или славеносрпски), стих, строфа и метар (антички, говорни), жанр (љубавна, родољубива, или епска поезија). Пјесника Јована Дошеновића (1781-1813) муза прекоријева што пјева само љубавне пјесме („Народ ти се узволновао / И чудесно дјело чини”), позивајући га да пјева „пјесноборке”. (Дошеновић 2005), док муза Павла Соларића (1779-1821) одбија да пјева Југовиће и Марка Краљевића - хоће само љубав (Соларић 1999).

Око књижевних дјела и њиховог смисла (дакле и функције) почињу прве велике полемике у раном периоду нове српске књижевности. Вук Караџић, првих година своје дјелатности, од 1814. до 1817, критикује језик српске штампе, јединих српских новина у Бечу, а потом језик, садржину и смисао Видаковићевих романа, замјерајућу романописцу што не зна српске обичаје, народни морал, ни народни језик, нити зна да створи досљедне карактере. Био је то увод у Вукову борбу за симбиозу писане литературе и живе фолклорно-патријархалне културе.

Ако је препородно доба почело у првој фази с просвјећивањем, ускоро средиште склопа функција књижевних дјела постаје испољавање и подстицање родољубља, колективног осјећања припадности српском народу. Алексије Везилић, аутор прве пјесничке збирке у српској књижевности (O спокојној жизни, 1788), држи да ће његова књига бити полезна (корисна), ,јуности славеносерпској”; одбацује сујевјерје, упозорава на штетност страсти (гордост, завист, гњев, зла савјест, чиста савјест...), док у „Песми о похвали рода српскаго” говори о јуначкој српској природи, о гостољубивости, доброчинству, славној историји, приписујући историјску трајност савременим својствима општнародног живота. (Лако је уочити везу између Доситејевих тврдњи о колективним својствима Срба, Везилићевих идеја и знатно млађе Вукове критике Видаковићевих романа због изневјеравања представа о тим својствима. Такође је лако уочити да су то рани трагови апологије српског народа посредством представе о његовој племенитој природи!)

Препородно доба потврђује и пропагира књигу, као основно средство савремене културе, посредника ширења и преноса знања (образовање, васпитање) те афирмације књижевног стварања, али и као робу која омогућује трговачке послове. ${ }^{2}$ Узевши је као вриједност по себи, Доситеј је још мора пропагирати полемички („Књиге, књиге, браћо моја, а не звона и прапорце”) ${ }^{3}$, док ускоро не постане метонимија савремене културе. У предговору за превод Голдонијеве комедије Трговци (1789), Емануил Јанковић тих година пита и упозорава младе Србе занатлије: „Ал камо Србљи? Гди сте? Што спавате? Зора је, пробудите се, време је веће.” Подршком књизи се досеже симбол пјесништва, високи Хеликон, писаће Видаковић (1811/1980: 12). Истицање националне тематике у приповједној прози такође се

\footnotetext{
${ }^{2}$ C. Новаковић опажа да је „нови српски књижевни рад” почео у вези са великим трговачким средиштима (Лајпциг, Беч, Пешта, Трст) (1900: 11).

${ }^{3}$ Тај се позив често не разумије контекстуално, како га треба разумјети. Сва три су појма (књиге, звона, прапорци) метонимије, знаци великих цјелина: књига - просвјећивања, а звона и прапорци - улагања новца у црквене грађевине и богаћење црквених достојанственика (прапорци су били дио њихове свечане запреге, накит). Доситеј се још у Буквицама бунио против богаћења далматинских игумана.
} 
испољава као снажно средство у придобијању читалаца. Видаковић жели да нацију нашу „Минерва свјашчаном својом лучом озарјава” (1814: 13); „Нација ће се наша просветити, облагородити и другим се славним народом уподобити” (Исто: 14). Неспоразум између Вука и Видаковића је у поимању садржине и квалитета романескног текста, а не у родољубљу: по Вуку, романсијер треба да познаје народне обичаје и да их приказује какви јесу, а да радњу и јунаке усаглашава са историјском истином и досљедношћу карактера (в. Деретић 1979: предговор, 25-26), док се Видаковић држао „романтическе” поетике слободног (неуједначеног, недосљедног и често неквалитетног) измишљања.

Стварање читалачке публике је, све до 60-их година 19. вијека, био општи циљ српских издавача и писаца (најчешће сами издају своје књиге преко претплате). Већ од Доситеја почиње да се обраћа посебна пажња женској публици, што ће се нагло ширити током романтизма (родољубље повезано емотивним својствима књижевних дјела), до „ослобађања женскиња” као демократско-политичког циља за вријеме Уједињене омладине српске. Требало је и оне који су се школовали на страним језицима и на туђој лектири привикнути на читање српских књига. Срби у Аустријском царству немају све до средине вијека српски као наставни предмет у гимназијама, већ латински, њемачки, мађарски, италијански, док међу Србима у Турском царству „у сто села” нема школе, свједочи Вук Караџић у Српском рјечникy („Школа”). Међутим, српске књиге је требало тек написати. Почетом 19. вијека једва да што има на народном (или доситејевском) језику, а тек су таква дјела могла будити вољу за српском књигом, а да она јача националну самосвијест, интересовање за српску историју (Видаковић) или за мелодрамске повијести религиозних епова (Ераковић 2008). Тек се са ширењем књиге на српском језику писци у шаљиво-сатиричним пјесмама или другим врстама почињу да изругују „худим Српкињама” и Србима (Соларић, Дошеновић, Никола Боројевић, Јован С. Поповић, Бранко Радичевић, Милица Стојадиновић Српкиња, Јован Јовановић Змај) који се стиде српског језика, или га не знају, говорећи мјешавином српског и неког другог језика; тема подсмијеха постаје и школовање у страним институтима као пут одрођавања (Лажа и паралажа Ј. С. Поповића, „Питомица” Н. Боројевића). Док је родољубље подстицано (позитивним) ликовима из српске прошлости, у сатири је изругивано отуђивање и напуштање националних традиција и националне самосвијести (себезнања, како би рекао Симо Милутиновић Сарајлија).

Видну промјену у функцију књижевних дјела уноси поезија. Послије родољубивих плачева и сентименталних јадиковки Захарије Орфелина, поучних пјесама и пјесама-портрета Алексија Везилића, Доситејева будница „На инсурекцију Сербијанов” (1804) најављује ослобађање српског народа и балканских народа од османске власти. С Мушицким, Дошеновићем, Соларићем, Мркаљем, Сарајлијом и Пачићем нагло се шири тематски и жанровски круг српске лирике (љубавна, описна, дидактичка, родољубива, митолошка, космичка, религиозна...). Пјеснички текст се у полемичким, критичким и теоријским ставовима аутора разматра с обзиром на национални, препородни аспект, на језик, стих, метар/ритам, синтаксу, стил (Дошеновић, Мркаљ, Мушицки...). Постаје битно, међутим, да пјесничка дјела обликом и садржином, реторичко-стилским фигурама, сликама, мислима наглашавају поетску поруку. Оштар рез у релативно спонтан ток српске лирике (Дошеновић) уноси Лу- 
кијан Мушицки (пролазећи и сам више поетичких фаза): афирмише стих класичне традиције (,,римски размјер”), а пригодно-дидактичке оде знаменитим личностима, пријатељима, младима и српском народу повезује с општим морално-националним идејама, објединив улогу учитеља родољубља, етичара, филолога, просвјетитеља и васпитача, у сталној ангажованости на „успостављању морала рода” (Павловић 2017: 258). Лукијанове пјесничке теме су редовно актуелне, поводом одређених догађаја, личности или питања као што су језик, метрика, оснивање новосадске гимназије и катедре за српски језик. Пјесме постају јавни гест, позив на акцију, коментар културних прилика и потреба, укључујући и читаоца као учесника.

Оде Лукијана Мушицког, међутим, и изричито и прећутно преносе поруке о смислу артистичке природе поезије, и тада с родољубивом (препородном) идејом: показати да српска муза може бити „убором Српкиња, ходом Римка”, тј. да се римски метар, метар латинске класике, може обући у српски језик. Пјеснички текст се изводи као експеримент, као вјежба, што је такође било једно од општијих тема или искушења препородног доба код малих словенских народа (Копитар о одама Лукијана Мушицког у латинском размјеру). ${ }^{45}$ У лирици Мушицког (и већине других пјесника кеговог доба и млађих) проширила се још једна њена функција: да је пјесма склониште пред животним невољама, утјеха и задовољство, средство очувања и испољавања личног идентитета. Коначно, већ на изласку из препородног доба, поезија Симе Сарајлије и Његоша огањ родољубља, спој земаљског и небесног, човјека и Бога, душе и космоса.

Приповједачка проза такође носи отворене или прећутне препородне циљеве (функције). Један од њих је развијање нове осјећајности и стварање осјећајног читаоца/читатељке као припадника свога рода. Већ је Доситеј Животом и прикљученијима те преводима сентиментално-моралистичких приповиједака утицао на јачање овакве оријентације, коју ће преузети или наставити генерација млађих прозаика (Стојковић, Видаковић). Читалац се привилегује као чиста и чувствитељна душа рода свога (Стојковић 1981: 9), синтагма која повезује нову емоциналност и националност. Буђење осјећајности кроз примјере осјећајних јунака (њихове патње, страдања и моралности истовремено) и избора ријечи овог домена, водили су ка препознатљивом сентименталистичком стилу. Индикативан је податак да је на Саломона Геснера Идиле (1827), у преводу Петра Матића, било стотине претплатника.

Обликовање национално свјесног читаоца, са осјећањем припадности свом народу једна је заједничких функција за све жанрове препородног периода српске књижевности, што се може повезати са истрајним похвалама српском роду (већ с Орфелиновим исказима о природи српског народа; са Доситејевим искуствима о српском народу од Баната до Далмације и Црне Горе). У том периоду, међутим, почиње и јавна критика или изругивање слабости и порока међу Србима. Доситеј је и у овом био најизиричитији, истичући и тада да говори из љубави према свом роду и из жеље да такве недостатке уклони. У таквим текстовима похвале смијењују

\footnotetext{
${ }^{4} \mathrm{O}$ томе више и рашчлањеније, Иванић (2011; 2015).

${ }^{5}$ Мушицки, „у једној једва заснованој литератури ствара две оде $<>$ испеване у старом алкајском метру, у којем је Хорације испевао тридесет и седам својих најдивнијих ода” (Копитар 1984: 124).
} 
сатиричке слике карактерне, моралне, националне изопачености, као што ће се обликовати у Стеријиним комедијама, досежући врхунац у Родољупияима.

Препородно доба је обједињено подређивањем јавне ријечи (књига, штампа) потврди националног идентитета (припадност, карактер, језик, вјера) и оплемењивању природног стања припадника народне заједнице (васпитање, учење). То се тиче свих посебних грана културе (књижевност, умјетности, хуманистика), њених установа (школа, штампа и штампарије, богословија, потом ће доћи музеји, књижевна друштва, позориште), а највише књиге као средишњег средства и метонимије културе. Просвјећивање постаје општи покрет, опште опредјељење, испрва на подстицајима са аустријског двора, касније као дио стања у европским културним средиштима.

Довољно је познато да је језик (српски) од почетка препородног доба узет најприје као средство просвјећивања (Доситеј), потом је постао предмет великих дилема и спорова, па засебан циљ (утврђивање граматичке и правописне норме), а на крају мјера вриједности (у поређењу с љепотом и старином других језика), те претпоставка опстанка дјела у културном памћењу нације. По себи је ова тврдња тривијална или саморазумљива, али је оправдава стање у језику књижевника овог доба. Прво, било је истакнутих писаца-Срба који су писали на другим језицима (нпр. Михаило Витковић); друго, савременици пишу на више варијаната тадашњег језика српске књиге (славеносрпски, црквенословенски=славјански, српски са елементима претходних двају језика, народни као језик Вукових збирки). Што је Мушицки поручио свом пријатељу, мађарско-српском пјеснику Михаилу Витковићу („Ти језик љуби. / Он је сокровиште мислеј рода; // Њим силно буде певац и витија/ Ко красним силам дремљуште духове; Он целом роду пут ко школи; / Српски ми варвитон узми и певај.”) (Мушицки 1938: 43), поновиће Вук Караџић у писму, такође свом старијем пријатељу, Лукијану Мушицком, упозоравајући га да не пјева на језику који ће његове оде оставити без будућности. ${ }^{6}$ Језик ће сам по себи (као српски, народни) преузети естетску функцију, не само да посредује поруке или мисли већ да избором саме ријечи и склопом (стилом) ријечи постаје вриједност (Радичевић, Његош, Стерија).

Класицисти су поезији дали највиши смисао у индивидуализацији пјесничке улоге у свијету ауторске и друштвене стварности. Романтичари ће почети дивинизовати и сакрализовати и поезију и пјесника. Милутиновићу је пјесник изасланик божанске душе, који даје лик ишчезњивом, дјелима лик божанствености, а смртника спаја с Вјечним. С Милутиновићем и његовим сљедбеником, Петром П. Његошем, поезија се ослобађа уско препородних функција, односно упија те функције у нове поетичке циљеве.

Можда би најједноставнији поглед на функцију поезије (и других врста) у српској књижевности препородног доба могао да се нађе у односу књижевне критике према Бранку Радичевићу. Најуочљивија су главна начела: филолошко полази од народног језика као највише мјере вриједности, претпостављајући и ангажовање

${ }^{6}$ Вук пише Мушицком, 10. децембра 1816: „Ове се оде Ваше све нама допадају неисказано; само ћу Вам ја пријатељски казати: да се чувате славенских ријечи као живе ватре: само славенске ријечи и ова смјеса српскога и славенског језика могу учинити да ваше оде и у језику не остану вјечне и класическе, као што су у мислима, у духу поетическом и народољубивом и у мајсторији.” (Караџић 1986: 356). 
на Вуковој страни (правопис и фолклорни основ писане књижевности); књижевноестетско држи до чисте лирике и одбацује учешће у књижевним споровима; етичконационално истиче начела моралности, одбија теме које су им несагласне (слобода еротске поезије) и на прво мјесто стављало национално јединство културне традиције (Иванић 2011: 206-207). Видљива разилажења ових начела су на трагу различитих погледа на смисао, природу и улогу поезије/књижевности у српској култури: док су једни од ње очекивали облик борбе за народни језик, други доминацију естетског, трећи су сматрали да је примарна њена морално-национална тенденција. Дијелом је од тих погледа зависила и судбина пјесничких опуса међу читаоцима: дјело Лукијана Мушицког је остало као примјер високе национално-моралне и дидактичке функције, али је изгубило естетски потенцијал. Како су основни препородни циљеви остварени, поезија/књижевност је заузела нова поља (љубав, породица, политика, социјални односи, психологија личности итд.). ${ }^{7}$

\section{Литература и извори}

Везилић А. Краткоје написаније о спокојној жизни. Прир. М. Д. Стефановић. Београд, 2011 [1788].

Видаковић М. Љубомир у Јелисијуму. Будим, 1814.

Видаковић М. Велимир и Босиљка. Прир. М. Клеут. Београд, 1982 [1811].

Деретић Ј. Почеци српске књижевне критике: Изабрани критички радови. Прир. Ј. Деретић. Нови Сад - Београд, 1979.

Ераковић Р. Религиозни еп српског предромантизма. Нови Сад, 2008.

Иванић Д. Ка генези српске поезије. Београд, 2011.

Илић Марковић Г., Кречмер А., Окука М. (прир.). An den Anfängen der serbischen Philologie: На почецима српске филологије, Salo debeloga jera libo azbukoprotres von Sava Mrkalj (1810-2010): Сало дебелога јера либо азбукопротрес Саве Мркаљьа. Peter Lang, 2012.

Караџић В. Мала простонародюа славеносрпска пјеснарища. Беч, 1814.

Караџић В. Српски рјечник. Беч, 1852 [1818].

Караџић В. Преписка. Прир. Г. Добрашиновић. Београд. 1987.

Копитар J. Serbica: Културно-историјске теме. Изабрао Ј. Погачник. Превео с немачког Т. Бекић. Нови Сад, 1984.

\footnotetext{
${ }^{7}$ Да би се разумио однос фикционалних дјела (рачунајући и лирику у одређеном смислу) према историјској (актуелној) стварности и имагинативном пољу људи те исте стварности у препородно доба, мора се поћи од више чињеница. Прва је: српски народ је несамосталан, расијан и потчињен у различитим државама, вјерски угрожен, без националних установа (школа итд.). Друга је: српски народ је имао извјесну (епску и писану) представу о својој прошлости и другачијим приликама (државна самосталност, истоврсност европским државама, манастири, Црква). Трећа је, у својим замислима водећи људи српског народа мисле о успостављању слободне српске државе и о политичко-културном повезивању Срба. Фикционалне творевине граде мост између имагинативног и историјског поља: предочавајући славну прошлост (или њене заблуде, уосталом) и њене ликове, оне надокнађују мањак таквих снага у свом времену и усмјеравају читаоца на будућност, на могућност остварења идеала национално-државне, па и индивидуалне слободе.
} 
Мркаљ С. Песме и списи. Прир. Ж. Ружић. Топуско, 1994.

Мушицки Л. Одабрани стихови Лукијана Мушициког. Приредио В. Стајић. Београд, 1938.

Новаковић С. Српска књига и њени читаоции. Београд, 1900.

Обрадовић Д. Сабрана дела, 1. Београд, 1961.

Орфелин 3. Петар Велики. Прев. З. Божовић, Д. Богдановић. Београд, 1974 [1774].

Павловић А. Пелен и мед. Српска дидактичка поезија од барока до романтизма. Н. Сад, 2017.

Петровић Н., Милисавац Ж. (ур.). Културно-политички покрети народа Хабсбуршке монархије у XIX веку. Нови Сад: Матица српска, 1983.

Соларић П. Гозба: Сабране пјесме. Прир. З. Крстановић. Београд, 1999.

Стојковић А. Аристид и Наталија. Прир. М. Клеут. Београд, 1981 [1801].

Prelog M. Slavenska renesansa: 1780-1848. Zagreb, 1924.

Душан М. Иванич

ФУНКЦИЯ ЛИТЕРАТУРНОГО ПРОИЗВЕДЕНИЯ В ЭПОХУ ВОЗРОЖДЕНИЯ

СЕРБСКОЙ КУЛЬТУРЫ

Резюме

В начале работы рассматривается понятие эпохи возрождения с опорой на более старую традицию изучения культуры славянских народов (М. Прелог). Эта эпоха охватывает период с 60-х гг. XVIII века (деятельность Захария Орфелина, а в особенности Доситея Обрадовича с 1783 г.) до 40-х гг. XIX века. Она стилистически, поэтически, с точки зрения языка очень гетерогенна (барокко, классицизм, сентиментализм/предромантизм, романтизм), но в целом пронизана идеями просвещения, общей пользы литературных произведений (апология книги), национального освобождения и объединения национальной культуры, патриотизма и свободы личности (новая чувствительность), а также дискуссиями и большими спорами о литературном языке/языке книги. Эпоха возрождения отмечена и упрочением основных литературных жанров (лирика, эпика, роман, драма и включение устной литературы в литературную систему) с глубоким пониманием их функций в процессе возрождения национальной культуры.

Ключевые слова: возрождение, функция, просвещенность, освобождение, патриотизм, язык, польза, нация, жанр. 